\title{
Potential role of p53 on metallothionein induction in human epithelial breast cancer cells
}

\section{LZ Fan' and MG Cherian*,'}

'Department of Pathology, University of Western Ontario, London, Ontario, N6A 5CI, Canada

The expression and induction of metallothionein has been associated with protection against oxidative stress and apoptosis. This study examines the effect of tumour suppressor protein p53 on metallothionein expression following $\mathrm{CdCl}_{2}$ treatment in eight human epithelial breast cancer cell lines differing in $\mathrm{p} 53$ and oestrogen-receptor status. Cells were treated with $10 \mu \mathrm{M}$ $\mathrm{CdCl}_{2}$ for $24 \mathrm{~h}$ and metallothionein protein levels were measured by cadmium binding assay. MCF7 cells which are p53positive (p53+) and oestrogen-receptor-positive showed a large induction in metallothionein synthesis by $10.79 \pm 1.36$-fold. Other breast cancer cell lines which are p53-negative (p53-) and oestrogen-receptor-negative or weakly oestrogenreceptor-positive showed a small induction ranging from $1.40 \pm 0.10$ to $3.65 \pm 0.30$-fold. RT-PCR analysis showed an induction of metallothionein mRNA in MCF7 cells by about 1.61 \pm 0.08 -fold, while in HCCl806 cells (p53-, oestrogenreceptor-negative) by $1.11 \pm 0.13$-fold, and in MDA-MB-23I (p53-, oestrogen-receptor-negative) by $1.25 \pm 0.06-$ fold. Metallothionein localisation was determined by immunohistochemical staining. Prior to metal treatment, metallothionein was localised mainly in the cytoplasm of MCF7 and MDA-MB-23I cells. After treatment with $10 \mu \mathrm{M} \mathrm{CdCl} 2$ for 24 h, MCF7 cells showed intense nuclear and cytoplasmic staining for metallothionein, while MDA-MB-23I cells showed staining in the cytoplasm with weak nuclear staining. Apoptosis induced by $10-40 \mu \mathrm{M} \mathrm{CdCl}_{2}$ at time points between 4 and $48 \mathrm{~h}$ was examined with TUNEL assay. In MCF7 cells, apoptosis increased with higher concentrations of $\mathrm{CdCl}_{2}$, it peaked at $6-8 \mathrm{~h}$ and appeared again at $48 \mathrm{~h}$ for all concentrations of $\mathrm{CdCl}_{2}$ tested. In MDA-MB-23I cells, apoptosis remained at low levels for $10-40 \mu \mathrm{M} \mathrm{CdCl}_{2}$ at all time points. Studies on cadmium uptake showed similar uptake and accumulation of cadmium at 8 and $24 \mathrm{~h}$ in all the cell lines. The data demonstrate that treatment of epithelial breast cancer cells with $10 \mu \mathrm{M} \mathrm{CdCl} 2$ for $24 \mathrm{~h}$ caused a greater induction of metallothionein protein and mRNA expression in p53+ and oestrogen-receptor-positive cells as compared to p53- and oestrogen-receptor-negative or weakly oestrogen-receptor-positive cells. This effect may be associated with the occurrence of apoptosis and suggests a role for p53 and oestrogen-receptor on the expression and induction of metallothionein in epithelial cells.

British Journal of Cancer (2002) 87, 1019 - 1026. doi:I0.1038/sj.bjc.6600549 www.bjcancer.com

(C) 2002 Cancer Research UK

Keywords: metallothionein; p53; apoptosis; breast cancer

The expression and induction of metallothionein (MT) has generally been associated with protection against oxidative stress and apoptosis. It has been reported that MT-null mice and cells derived from them were more sensitive to the toxic effects of heavy metals such as cadmium (Klaassen et al, 1999), toxic agents such as hydrogen peroxide and tert-butyl hydroperoxide (Chubatsu and Meneghini, 1993; Schwarz et al, 1994), and radiation exposure (Cai et al, 1999) as compared to MT-wildtype and MT I-overexpressing mice. Cells pre-induced to express MT were also more resistant against the toxic effects of cadmium (Goering and Klaassen, 1984; Klaassen et al, 1999) and radiation exposure (Cai et al, 1999) as compared to control cells. In human T cell and breast carcinoma cell lines, down-regulation of MT with antisense MT oligomers not only inhibited growth of the cells, but also activated apoptosis (Abedel-Mageed and Agrawal, 1997; Tsangaris and Tzortzatou-Stathopoulou, 1998). In studies using tumour cell lines, it was found that tumour cells with a high expression of MT were more resistant against the toxic effects

*Correspondence: Dr MG Cherian; E-mail: mcherian@uwo.ca Received 16 January 2002; revised 29 April 2002; accepted 5 July 2002 of anticancer agents such as cisplatin as well as radiation exposure (Kondo et al, 1995; Lazo et al, 1998). In addition, in both human primary hepatocellular carcinoma and metastatic carcinoma, the MT levels were low and had higher number of apoptotic cells as compared to normal liver (Cai et al, 1998; Deng et al, 1998).

The potential role of MT on modulation of apoptosis is unclear. Antioxidant properties of MT may contribute to its protective effects (Greenstock et al, 1987; Cai et al, 1996). In fact, the synthesis of MT was shown to be induced several-fold during oxidative stress (Sato and Bremner, 1993) to protect the cells against cytotoxicity (Aschner et al, 1998) and DNA damage (Cai et al, 1995). In particular, MT synthesis is induced following treatment with cadmium, an environmental pollutant that is able to cause oxidative stress, DNA damage and apoptosis (El Azzouzi et al, 1994; Yang et al, 1997). The protective role of MT may also depend on the nuclear/cytoplasmic localisation of MT in the cell. In general, cytoplasmic MT protects against cytotoxicity whereas nuclear MT protects against genotoxicity (Schwarz et al, 1994; Woo and Lazo, 1997; Cherian and Apostolova, 2000).

The tumour suppressor protein $\mathrm{p} 53$ is one of the most frequently activated proteins in apoptosis. p53 is able to 
respond to different cellular stresses such as DNA damage, hypoxia, oxidative stress, and oncogene activation. Upon activation, p53 initiates a number of cellular activities that can ultimately culminate in G1 or G2 cell cycle arrest and DNA repair, apoptosis, or other cellular changes (Schwartz and Rotter, 1998). As a critical cellular mediator of the response to genotoxic damage, P53 has a direct role in maintaining the integrity of the genome. Loss of p53 activity has been associated with tumour progression and unfavourable prognosis of the tumour (Symonds et al, 1994). Recently, it was found that an association exists between MT expression and p53 expression in small cell carcinoma of the lung (Joseph et al, 2001). Since both MT and p53 are involved in responding to oxidative stress and apoptosis, the present study was undertaken to investigate the effect of p53 on MT expression and induction in human epithelial breast cancer cells.

MT expression in breast cancer has been associated with a lower number of apoptotic cells (Abdel-Mageed and Agrawal, 1997) and a poor prognosis of the cancer (Haerslev et al, 1995; Oyama et al, 1996). Recently, certain studies have demonstrated that oestrogen receptor-positive $(\mathrm{ER}+)$ breast cancer cells showed lower expression of MT as compared to oestrogen receptor-negative (ER-) cells (Friedline et al, 1998). Possibly, p53 may be another factor in determining MT expression. Since p53 is mutated in more than $70 \%$ of human breast cancers (Callahan and Campbell, 1989), it is possible to examine the effects of p53-positive (p53+) as well as p53-negative $(\mathrm{p} 53-)$ breast cancer cell lines. These cell lines also show differential expression of oestrogen receptor. In this study, MT expression and induction following cadmium exposure were investigated in eight epithelial breast cancer cell lines differing in p53 and ER expression.

\section{MATERIALS AND METHODS}

\section{Cell culture}

Human epithelial breast cancer cell lines MCF7 and HCC1806 were obtained from Dr Rodenheiser; HCC1419 and HCC1569 from ATCC; MDA-MB-231, MDA-MB-468 and HS578t from Drs Laird and Lala; and MDA-MB-435 from Drs Ferguson and Koropatnick. MCF7 cells were grown in Dulbecco's Modified Essential Medium (DMEM) supplemented with $10 \%$ foetal bovine serum (FBS). HCC1806, HCC1419, HCC1569, MDA-MB-231 and MDA-MB468 cells were grown in RPMI1640 medium supplemented with $10 \%$ FBS. HS578t cells were grown in RPMI1640 medium supplemented with $10 \%$ FBS and $10 \mu \mathrm{g} \mathrm{ml}^{-1}$ of insulin. MDA-MB-435 cells were grown in Minimum Essential Medium Alpha containing ribonucleosides and deoxyribonucleosides and supplemented with $10 \%$ FBS. The epithelial breast cancer cell lines differ in p53 and ER expression (Table 1).

\section{Cell viability assay}

Cell viability following $\mathrm{CdCl}_{2}$ treatment was measured using Intergen's Procheck Cell Viability Assay (Intergen Co., Purchase, NY, U.S.A.) based on the conversion of XTT (sodium3,3'-\{1[(phenylamino) carbonyl]-3,4 - tetrazolium $\}$ bis(4-methoxy-6-nitro)benzene sulphonic acid) from an oxidized tetrazole to a reduced formazan (Scudiero et al, 1988). Cells were seeded into 96-well plates with $10^{4}$ cells well ${ }^{-1}$ and allowed to attach for $24 \mathrm{~h}$. Cells were treated with $10-100 \mu \mathrm{M}$ of $\mathrm{CdCl}_{2}$ for $12 \mathrm{~h}$ and then washed twice with PBS to stop the treatment. To the wells, $100 \mu \mathrm{l}$ of media and $20 \mu \mathrm{l}$ of the assay reagent were added and cells were incubated under growth conditions for $4 \mathrm{~h}$. Optical densities were read at $475 \mathrm{~nm}$ in a microplate spectrophotometer and cell viability was expressed as a per cent of control.
Table I Oestrogen-receptor and p53 expression in human epithelial breast cancer cell lines

\begin{tabular}{|c|c|c|}
\hline Breast cancer cell lines & $\begin{array}{l}\text { Oestrogen-receptor } \\
\text { (ER) status }\end{array}$ & p53 status \\
\hline MCF7 & $t^{c}$ & $t^{\mathrm{a}}$ \\
\hline $\mathrm{HCCl} 806$ & $-{ }^{d}$ & $-^{d}$ \\
\hline $\mathrm{HCCl} 419$ & $-{ }^{d}$ & $-^{d}$ \\
\hline $\mathrm{HCCl} 569$ & $-^{d}$ & $-^{d}$ \\
\hline MDA-MB-23I & $-{ }^{c}$ & $-{ }^{a}$ \\
\hline HS578t & $-^{c}$ & $-{ }^{a}$ \\
\hline MDA-MB-468 & $\pm^{c}$ & $--^{b}$ \\
\hline MDA-MB-435 & $\pm^{c}$ & $-{ }^{\mathrm{a}}$ \\
\hline
\end{tabular}

+Presence of wild-type oestrogen receptor or p53. - No wild-type oestrogen receptor or p53. \pm Weakly detectable expression of oestrogen-receptor mRNA using RT-PCR at 30 cycles (Zeillinger et al, 1996). ${ }^{a} O^{\prime}$ Connor et al, 1997.

bunnebaum et al, 1991. 'Zeillinger et al, 1996. 'ATCC cell lines.

\section{Estimation of MT}

Cells grown in $75-\mathrm{cm}^{2} \mathrm{~T}$ flasks were treated with $10 \mu \mathrm{M} \mathrm{CdCl}$ for $24 \mathrm{~h}$ and then washed twice with PBS. Cells were collected by trypsinisation followed by centrifugation at 2000 r.p.m. for 2 min. Quantification of MT was performed by a ${ }^{109}$ cadmiumhaeme saturation assay as previously described (Eaton and Cherian, 1991). Briefly, the cell pellet was resuspended in $630 \mu \mathrm{l}$ of deionised water and frozen and thawed to lyse the cells. To a $300 \mu \mathrm{l}$ aliquot, $1 \mathrm{ml}$ of a $30 \mathrm{~mm}$ Tris- $\mathrm{HCl}$ buffer $(\mathrm{pH} 8.0)$ and $1 \mathrm{ml}$ of a 5 p.p.m. ${ }^{109} \mathrm{Cd}$ solution with known specific activity were added to saturate the metal-binding sites of MT. Rat haemolysate was added to remove excess $\mathrm{Cd}$, followed by heat treatment in a water bath to precipitate Cd-hemoglobin and other proteins, with the exception of MT which is heat stable. The denatured proteins were then removed by centrifugation at 10000 r.p.m. for $2 \mathrm{~min}$. The steps of haemolysate addition, heat denaturation and centrifugation were repeated three times. The Cd concentrations in the final supernatant were calculated from the radioactivity of the ${ }^{109} \mathrm{Cd}$ measured by a $\gamma$ counter (1272 Clinigamma, LKB Wallac; Turku, Finland), with a counting efficiency of $75 \%$, and were converted to MT concentration on the basis of $7 \mathrm{~g}$ atoms of cadmium/MT. An additional aliquot of the lysed cell suspension was assayed for protein with Bio-Rad Protein Assay (Bio-Rad Laboratories, Hercules, CA, USA). The total MT concentrations in the cells were expressed as $\mu \mathrm{g}$ MT mg protein $^{-1}$.

\section{Immunohistochemical staining for MT}

Cells were seeded in 4 -chamber slides with $5 \times 10^{4}$ cells per chamber and allowed to attach for $24 \mathrm{~h}$. Cells were then treated with $10 \mu \mathrm{M} \mathrm{CdCl} 2$ for $24 \mathrm{~h}$ and then washed twice with PBS. The immunohistochemical staining technique for MT was previously described (Deng et al, 1998). Briefly, cells were fixed in $1 \%$ paraformaldehyde in PBS for $10 \mathrm{~min}$ at room temperature. Endogenous peroxidase activity was inactivated by quenching the cells in $3.0 \%$ hydrogen peroxide for $5 \mathrm{~min}$. Cells were incubated with $10 \%$ normal goat serum for $45 \mathrm{~min}$, followed by incubation with polyclonal rabbit anti-MT serum $(1: 400)$ for $2 \mathrm{~h}$ at room temperature. This antibody was generated against a polymer of rat liver MT but readily cross-reacts with human MT. Normal rabbit serum substituted for the primary antibody was used as negative control. Subsequently, cells were incubated with biotinylated goat antirabbit IgG and then with avidin-biotin horseradish peroxidase complex following the manufacturer's instruction (ABC Kit, Vector Laboratories, Burlingame, CA, USA). Staining was developed with $0.05 \% 3,3^{\prime}$-diaminobenzidine tetrahydrochloride (DAB) with 
$0.33 \%$ hydrogen peroxide, counterstained with haematoxylin and $0.3 \%$ ammonia solution, dehydrated and mounted.

\section{RNA isolation and RT - PCR}

Cells grown in $75-\mathrm{cm}^{2} \mathrm{~T}$ flasks were treated with $10 \mu \mathrm{M} \mathrm{CdCl}$ for $24 \mathrm{~h}$ and then washed twice with PBS. Total RNA was isolated from the cells with TRIzol Reagent (GIBCO BRL, Life Technologies, Grand Island, NY, USA) according to the manufacturer's instructions. RNA was extracted with chloroform followed by centrifugation to separate the solution into aqueous and organic phases. RNA was recovered from the aqueous phase by precipitation with isopropyl alcohol and suspended in diethyl pyrocarbonate-treated water. The concentration of isolated RNA was measured by spectrophotometry at $260 \mathrm{~nm}$ and RNA samples with purity greater than $1.6(260 / 280 \mathrm{~nm}$ ratio $)$ were used for reverse transcription.

First strand cDNA synthesis was performed using Superscipt-II system (GIBCO BRL, Life Technologies, Gaithersburg, MD, USA). RNA was added to Oligo (dT) primers (GIBCO BRL), denatured at $70^{\circ} \mathrm{C}$, and quenched on ice for $10 \mathrm{~min}$. Five micrograms of RNA were reverse transcribed for $50 \mathrm{~min}$ at $42^{\circ} \mathrm{C}$ with superscript Moloney murine leukaemia virus reverse transcriptase (GIBCO BRL) and dNTP in a total reaction volume of $20 \mu \mathrm{l}$. The reaction was terminated by a $7 \mathrm{~min}$ incubation at $70^{\circ} \mathrm{C}$.

The resulting reverse transcribed product was then used for PCR amplification performed with the oligonucleotide primers specific for human MT-II (GIBCO BRL). MT-II primer sequences were as follows: 5-CTC TTC AGC ACG CCA TGG AT-3 (sense) and 5-CGC GTT CTT TAC ATC TGG GA-3 (antisense). The predicted size of the amplified product (cDNA) was $203 \mathrm{bp}$ for MT-II. PCR was performed under the following conditions with a thermal cycler. Each sample contained $1 \mu \mathrm{M}$ of the sense and antisense primers for MT-II, $1 \times$ PCR buffer (GIBCO BRL), $1.0 \mathrm{mM} \mathrm{MgCl}_{2}$

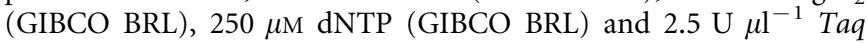
DNA polymerase (GIBCO BRL) in a final volume of $50 \mu \mathrm{l}$. PCR was carried out for 23 cycles with denaturation at $94^{\circ} \mathrm{C}$ for $45 \mathrm{~s}$, annealing at $55^{\circ} \mathrm{C}$ for $30 \mathrm{~s}$, and extension at $72^{\circ} \mathrm{C}$ for $1 \mathrm{~min}$ $30 \mathrm{~s}$, with a final elongation step at $72^{\circ} \mathrm{C}$ for $10 \mathrm{~min}$. Simultaneously, a housekeeping gene, $\beta$-actin, was amplified in a separate set of tubes using the same RT product and similar cycling parameters. $\beta$-actin primer sequences were as follows: $5^{\prime}$-CCT CTA TTC CAA CAC AGT GC-3' (sense) and 5'-CAT CGT ACT CCT GCT TGC TG-3' (antisense), with predicted product size of $210 \mathrm{bp}$.

Following PCR, a $10 \mu \mathrm{l}$ aliquot of the RT-PCR cDNA was electrophoresed in 3\% agarose gel in Tris/acetic acid/EDTA (TAE) buffer for $70 \mathrm{~min}$ at $100 \mathrm{~V}$, stained with ethidium bromide, and visualised with UV light. The intensity of the cDNA bands was analysed by densitometry, and MT-II mRNA expression was normalised with $\beta$-actin.

\section{In situ apoptosis detection}

Cells were seeded in 8 -chamber slides with $5 \times 10^{4}$ cells per chamber and allowed to attach for $24 \mathrm{~h}$. Cells were then treated with $\mathrm{CdCl}_{2}$ for varying time points and treatment was stopped by washing twice with PBS. The method of TdT-mediated deoxyribonucleotide triphosphate-digoxigen nick end labelling (TUNEL) was used for in situ labelling of apoptotic cells. Staining was conducted according to the manufacturer's instruction (ApopTag Peroxidase In Situ Apoptosis Detection Kit, Intergen Co.). Briefly, cells were fixed in $1 \%$ paraformaldehyde in PBS for $10 \mathrm{~min}$ at room temperature, followed by post-fix in pre-cooled ethanol: acetic acid $2: 1$ for $5 \mathrm{~min}$ at $-20^{\circ} \mathrm{C}$. Endogenous peroxidase was inactivated by quenching the cells in $3.0 \%$ hydrogen peroxide for $5 \mathrm{~min}$. Terminal deoxynucleotidyl transferase (TdT) enzyme and digoxigenin-labelled dUTP were applied to the sections for $1 \mathrm{~h}$ at $37^{\circ} \mathrm{C}$. Cells were then washed in stop/wash buffer and treated with anti-digoxigenin peroxidase conjugate for $30 \mathrm{~min}$ at room temperature. Staining was developed with $0.05 \%$ $3,3^{\prime}$-diaminobenzidine tetrahydrochloride (DAB) with $0.33 \%$ hydrogen peroxide, counterstained with haematoxylin and $0.3 \%$ ammonia solution, dehydrated and mounted. Apoptotic cells were examined at $400 \times$ magnification, counted in 10 randomly selected fields, and expressed as a per cent of total cells.

\section{Determination of $\mathrm{CdCl}_{2}$ uptake}

Cells grown in $75-\mathrm{cm}^{2} \mathrm{~T}$ flasks were treated with $10 \mu \mathrm{M}$ of ${ }^{109} \mathrm{CdCl}_{2}$ and incubated as described earlier for 8 or $24 \mathrm{~h}$, and then washed twice with PBS. Cells were collected by trypsinisation followed by centrifugation at 2000 r.p.m. for $2 \mathrm{~min}$. The cell pellet was resuspended in deionised water and frozen and thawed to lyse the cells. Disintegrations per minute (d.p.m.) of ${ }^{109} \mathrm{CdCl}_{2}$ taken up by the cells were measured by a $\gamma$ counter (1272 Clinigamma, LKB Wallac) with a counting efficiency of $75 \%$. An additional aliquot of the lysed cell suspension was assayed for protein with Bio-Rad Protein Assay (Bio-Rad Laboratories) and d.p.m. was expressed as d.p.m. mg protein ${ }^{-1}$.

\section{Statistical analysis}

Results are expressed as mean \pm s.e. The statistical evaluation of the results was performed by one-way ANOVA analysis, followed by student's $t$-test using the error calculated from ANOVA. Significance was established at $P<0.05$.

\section{RESULTS}

\section{Cell viability after exposure to cadmium}

The cell viability of cell lines MCF7 (ER+, p53+), HCC1806 (ER-, p53-) and MDA-MB-231 (ER-, p53-) was assessed after exposure to $10-100 \mu \mathrm{M} \mathrm{CdCl}_{2}$ for $12 \mathrm{~h}$ (Figure 1). The viability of MCF7 cells was unaffected by $10-30 \mu \mathrm{M} \mathrm{CdCl}_{2}$ treatment for $12 \mathrm{~h}$, but decreased to $96 \%$ in response to $40 \mu \mathrm{M} \mathrm{CdCl}_{2}$. The viability of MCF7 cells further decreased as the concentration of $\mathrm{CdCl}_{2}$ was increased, and was $0 \%$ with $80 \mu \mathrm{M} \mathrm{CdCl}_{2}$ exposure. Both HCC1806 and MDA-MB-231 cells were more resistant to $\mathrm{CdCl}_{2}$ treatment. HCC1806 cells did not show any decrease in cell viability in response to $10-100 \mu \mathrm{M} \mathrm{CdCl}_{2}$. MDA-MB-231 cells showed a $6 \%$ decrease in viability after exposure to $70 \mu \mathrm{M} \mathrm{CdCl}_{2}$, and at $100 \mu \mathrm{M} \mathrm{CdCl}_{2}$ the viability was $85 \%$.

\section{Induction of MT by cadmium}

When these cells were treated to $\mathrm{ZnSO}_{4}(30-60 \mu \mathrm{M})$, no significant differences in MT induction were observed in the different cell lines (data not shown). When cells were treated with oestrogen (1-100 nM), there was no induction of MT (data not shown). The induction of MT by cadmium was examined in eight epithelial breast cancer cell lines differing in p53 and ER status (Table 1). Cells were treated with $10 \mu \mathrm{M}$ of $\mathrm{CdCl}_{2}$ for $24 \mathrm{~h}$ to induce MT expression and basal and induced MT levels were measured with the ${ }^{109} \mathrm{Cd}$-haeme assay (Figure 2). The cell lines showed a range of basal MT levels, with MCF7 at $0.55 \pm 0.05 \mu \mathrm{g}$ MT mg protein ${ }^{-1}$ and the other cell lines at $0.43 \pm 0.02$ to $2.06 \pm 0.11 \mu \mathrm{g} \mathrm{MT} \mathrm{mg}$ protein $^{-1}$. Following the induction of MT with $10 \mu \mathrm{M} \mathrm{CdCl}_{2}$ for $24 \mathrm{~h}$, MCF7 cells showed the highest MT expression at $5.93 \pm 0.25 \mu \mathrm{g}$ MT mg protein ${ }^{-1}$, while other cell lines showed lower MT expression ranging from $1.54 \pm 0.06$ to $3.21 \pm 0.19 \mu \mathrm{g}$ MT mg protein ${ }^{-1}$. The ratios of induced MT/basal MT were calculated, and interestingly, MCF7 cells showed the highest induction 


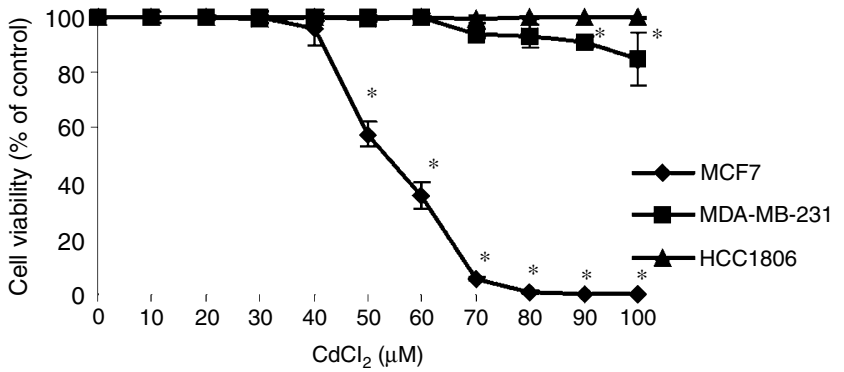

Figure I Effects of $\mathrm{CdCl}_{2}$ on cell viability. MCF7, MDA-MB-23I, and $\mathrm{HCCl} 806$ cells were treated with various concentrations of $\mathrm{CdCl}_{2}$ for $12 \mathrm{~h}$. Cell viability was determined with Procheck Cell Viability Assay and expressed as a per cent of control. Results are mean \pm s.e. of three independent experiments. * Significantly different from control at $P<0.05$.

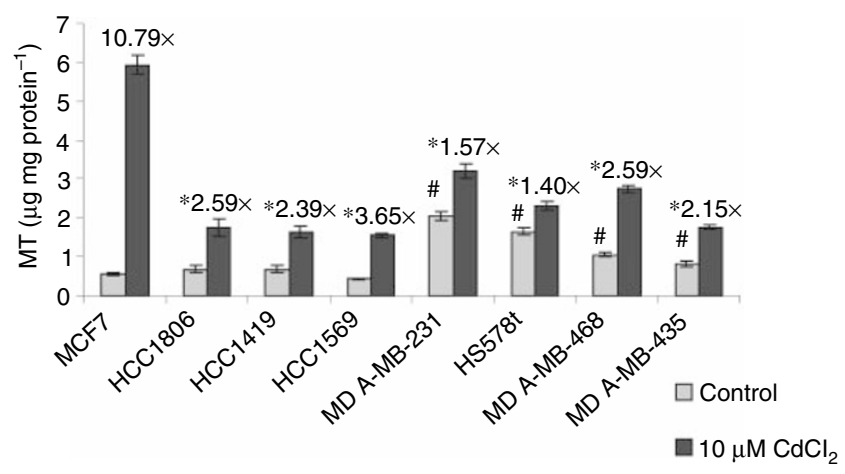

Figure 2 Induction of MT expression with $\mathrm{CdCl}_{2}$. Epithelial breast cancer cells were treated with $10 \mu \mathrm{M} \mathrm{CdCl}_{2}$ for $24 \mathrm{~h}$. MT protein levels were determined with ${ }^{109}$ Cadmium-haeme assay and expressed as $\mu \mathrm{g}$ MT mg total protein ${ }^{-1}$. Results are mean + s.e. of three independent experiments. *Ratio of induced MT level/basal MT level is significantly different from MCF7 cells at $P<0.05$. \# Basal MT level is significantly different from MCF7 cells at $P<0.05$.

of MT by $10.79 \pm 1.36$-fold, while other cell lines showed induction by $1.40 \pm 0.10$ to $3.65 \pm 0.30$-fold. Treatment with $10 \mu \mathrm{M} \mathrm{CdCl}_{2}$ for $24 \mathrm{~h}$ strongly induced MT in MCF7 cells, which are p53+/ER+, compared to a smaller induction in other cell lines that are p53-/ER - or p53-/ER \pm .

\section{Localisation of MT after exposure to cadmium}

The localisation of MT in MCF7 and HCC1806 cells after treatment with $10 \mu \mathrm{M} \quad \mathrm{CdCl}_{2}$ for $24 \mathrm{~h}$ was determined by immunohistochemical staining using a polyclonal rabbit antibody to MT. Prior to $\mathrm{CdCl}_{2}$ treatment, only a light staining for MT was observed, mainly in the cytoplasm of both cell lines (Figure 3a,b). After exposure to $10 \mu \mathrm{M} \mathrm{CdCl}_{2}$ for $24 \mathrm{~h}$, intense staining was observed in the cytoplasm and nucleus of MCF7 cells (Figure 3c). In contrast, HCC1806 cells showed staining in the cytoplasm with a weak staining in the nucleus (Figure 3d). Negative control slides incubated with normal rabbit serum showed no staining for MT.

\section{Induction of MT mRNA expression by cadmium}

To investigate the induction of MT mRNA by cadmium, the cell lines MCF7, HCC1806 and MDA-MB-231 were treated with $10 \mu \mathrm{M} \mathrm{CdCl}_{2}$ for $12 \mathrm{~h}$ and mRNA levels were compared. Total RNA was isolated from the cell lines and $5 \mu \mathrm{g}$ of RNA was subjected to RT-PCR analysis using a primer specific for human MT-II and a primer for $\beta$-actin simultaneously. PCR products were electrophoresed on agarose gel and stained with ethidium bromide. The intensities of the bands were measured and MT-II mRNA expression was normalised with $\beta$-actin. At 23 cycles of PCR, this analysis showed a significant increase in MT-II mRNA expression in MCF7 cells following $\mathrm{CdCl}_{2}$ treatment, but little change in HCC1806 and MDA-MB-231 cells was observed (Figure 4). The induction of MT-II mRNA was calculated and expressed as a ratio of treated cells/control cells. Results showed a greater induction of MT-II mRNA expression in MCF7 cells (by $1.61 \pm 0.08$-fold) than in HCC1806 cells and MDA-MB-231 cells (by $1.11 \pm 0.13$ and $1.25 \pm 0.06$-fold, respectively).

\section{Detection of apoptosis induced by cadmium}

The terminal deoxyribonucleotidyl transferase mediated dUTP nick end labelling method (TUNEL) was used to determine the number of apoptotic bodies in epithelial breast cancer cells present following $\mathrm{CdCl}_{2}$ treatment. Based on the cell viability data, the concentrations of 10 to $40 \mu \mathrm{M}$ of $\mathrm{CdCl}_{2}$ were selected to treat MCF7 and MDA-MB-231 cells for different time points between 4 to $48 \mathrm{~h}$ to induce apoptosis. Apoptotic cells were identified by the appearance of specific nuclear staining, condensed nucleus and/or formation of apoptotic bodies as examined at $400 \times$ magnification (Figure 5). The number of apoptotic cells was expressed as a per cent of total cells counted. At 10,20,30 and $40 \mu \mathrm{M}$ of $\mathrm{CdCl}_{2}$, the highest number of apoptotic bodies in MCF7 cells was observed between $6-8 \mathrm{~h}$ and again at $48 \mathrm{~h}$ (Figure 6a, data shown only for $40 \mu \mathrm{M} \mathrm{CdCl}_{2}$ treatment). In MDA-MB-231 cells, apoptosis remained at a constant low level at all the time points examined between 4 to $48 \mathrm{~h}$ (Figure 6a, data shown only for $40 \mu \mathrm{M} \mathrm{CdCl}_{2}$ treatment). In MCF7 cells at all time points tested, the number of apoptotic cells increased as the concentration of $\mathrm{CdCl}_{2}$ was increased, while in MDA-MB-231 cells, there was again a constant low level of apoptosis (Figure $6 \mathrm{~b}$, data shown only for $8 \mathrm{~h}$ time period).

\section{Uptake of cadmium by different cell lines}

The uptake of Cd by MCF7, MDA-MB-231, and MDA-MB-435 cells was determined by treating the cells with ${ }^{109} \mathrm{CdCl}_{2}$ and then measuring radioactivity. The results are expressed as d.p.m. mg protein $^{-1}$. The results show no significant differences in cadmium uptake in these cell lines at 8 or $24 \mathrm{~h}$ of treatment (Figure 7). The data suggest a similar $\mathrm{Cd}$ uptake and uniform accumulation of $\mathrm{Cd}$ in these cell lines.

\section{DISCUSSION}

This study demonstrates a potential role of p53 on the expression and induction of MT in human epithelial breast cancer cells. Our results show that epithelial breast cancer cells with differential p53 expression exhibit differences in induction of MT, and response to toxicity following treatment with cadmium. Although cadmium caused induction of MT in all cell lines regardless of ER and p53 status, MCF7 cells showed a much higher induction in MT protein and mRNA levels as compared to cell lines that are p53- and $\mathrm{ER}-/ \pm$ (Figure 2). Cell viability results and TUNEL staining for apoptosis both showed a greater sensitivity of MCF7 cells to toxicity induced by cadmium as compared to MDA-MB-231 (p53-, ER -) and HCC1806 (p53-, ER-) cells (Figures 1 and 6). To investigate whether these differences are due to differential accumulation of cadmium, the uptake of cadmium in the cell lines was determined by treating the cells with ${ }^{109} \mathrm{CdCl}_{2}$ and calculating the radioactivity as ${ }^{109} \mathrm{Cd}$ d.p.m. mg protein ${ }^{-1}$. Our studies on cadmium uptake showed that the different cell lines have similar 

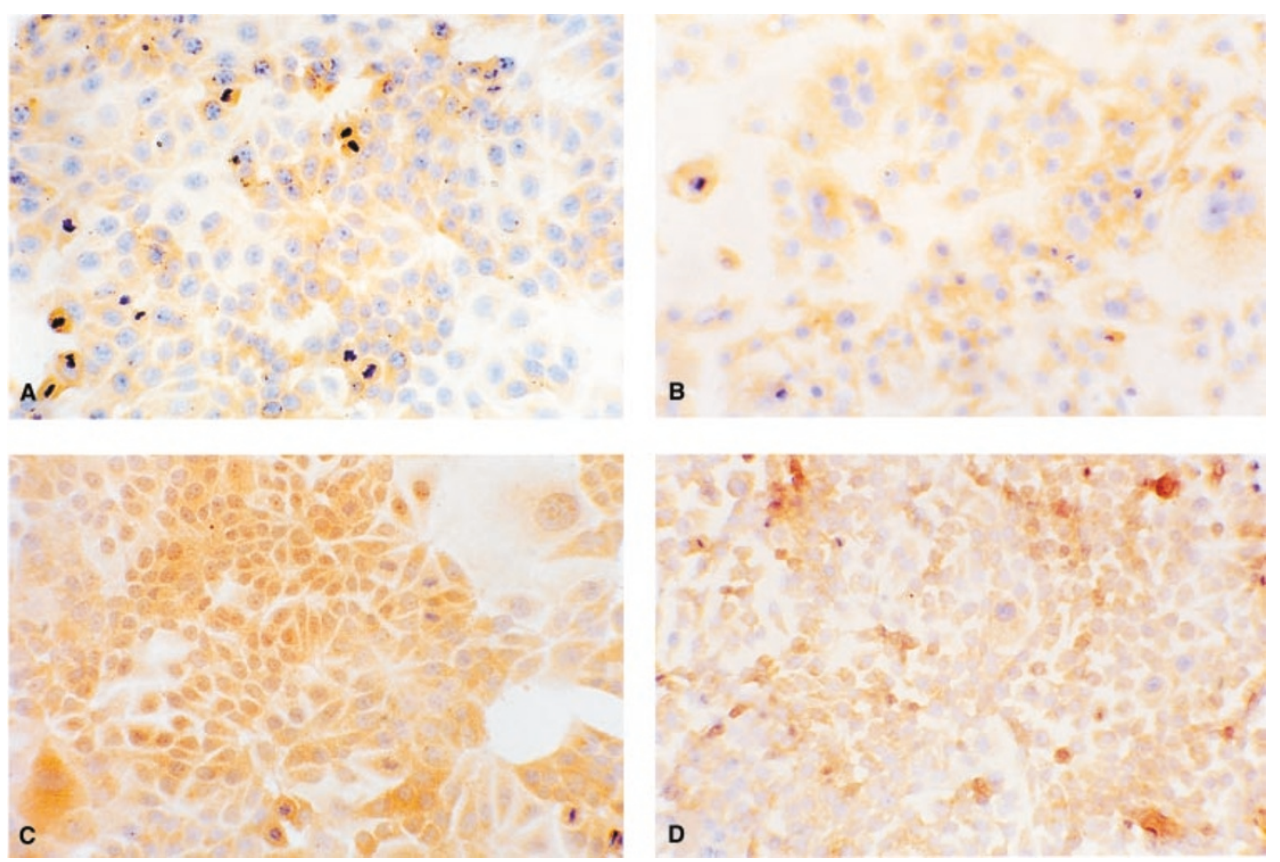

Figure 3 Immunohistochemical staining for MT with rabbit polyclonal anti-MT serum which cross-reacts with human MT. Control cells: MCF7 (A), and $\mathrm{HCCl} 806$ (B). Cells treated with $10 \mu \mathrm{M} \mathrm{CdCl}$ for 24 h: MCF7 (C), and HCCI 806 (D). Positive staining is brown in colour. Magnification $400 \times$.
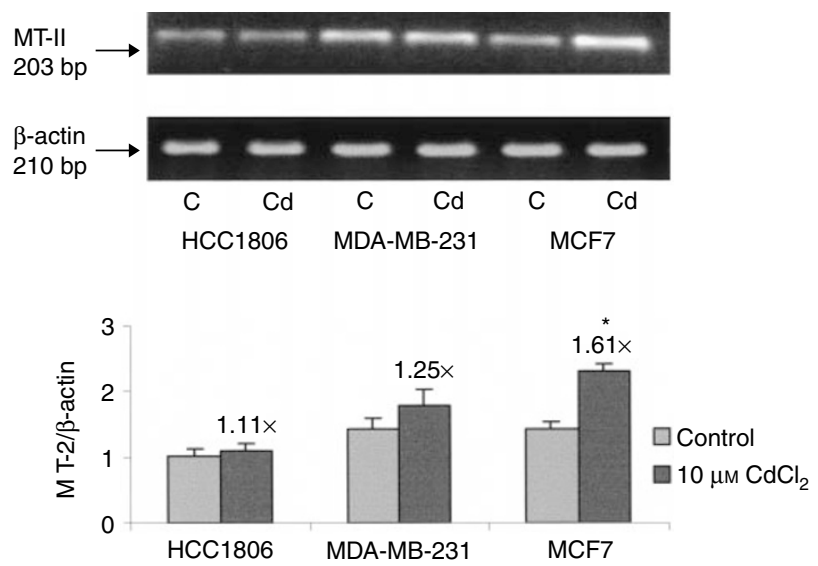

Figure 4 MT-II expression at 23 PCR cycles. RT - PCR was used to analyse total RNA samples derived from three epithelial breast cancer cell lines: HCCI806, MDA-MB-2I3, and MCF7. PCR products were electrophoresed on agarose gel and stained with ethidium bromide. Control cells are represented by $\mathrm{C}$ and cells treated with $10 \mu \mathrm{M} \mathrm{CdCl}_{2}$ for $24 \mathrm{~h}$ are represented by $\mathrm{Cd}$. Intensities of cDNA bands were analysed by densitometry and MT-II mRNA expression was normalised with $\beta$-actin. Changes in MT-II mRNA expression following treatment were calculated as a ratio of treated cells/control cells and indicated in the graph. Results are mean \pm s.e. of three independent experiments. *Significantly different from control cells at $P<0.05$.

cadmium uptake and accumulation (Figure 7). Thus, higher MT induction and greater sensitivity to cadmium-induced toxicity in MCF7 cells is not a consequence of greater accumulation of cadmium, but may be a consequence of positive p53 expression. The presence of p53 in MCF7 cells likely mediates the dose- and time-dependent apoptosis observed during treatment with $\mathrm{CdCl}_{2}$. In contrast, the absence of p53 in MDA-MB-231 cells appears to render the cells resistant to apoptosis when treated with $\mathrm{CdCl}_{2}$ $(10-40 \mu \mathrm{M})$ from 4 to $48 \mathrm{~h}$.
The presence of wild-type p53 and occurrence of apoptosis may be important indicators of MT expression, since the expression and induction of MT has been associated with protection against oxidative stress and apoptosis. Cadmium is a potent inducer of MT synthesis that not only acts through metal response elements of the MT gene to up-regulate gene transcription (Karin et al, 1984), but can also cause intracellular free radical generation and lipid peroxidation, DNA damage and a characteristic apoptotic response (El Azzouzi et al, 1994; Yang et al, 1997). Apoptosis induced by cadmium is preceded by the participation of oxidative stress, with up-regulation of oxidant stress genes such as glutathione S-transferase and $\gamma$-glutamylcysteine synthetase, activation of redox sensitive transcription factor AP-1 and NF- $\kappa \mathrm{B}$, as well as induction of MT-1 and MT-II synthesis (Hart et al, 1999; Zhou et al, 1999). Several mechanisms may be involved in the protective effect of MT against metal toxicity and apoptosis. MT has been shown to bind cadmium and to sequester it away from important cellular organelles (Goering and Klaassen, 1984). In addition, MT may have antioxidant properties because of its high cysteine content which may protect against DNA damage (Cai et al, 1996). A recent study has shown that treatment of MCF7 cells with $10 \mu \mathrm{M} \mathrm{CdCl}_{2}$ can increase MT-IIA isoform and can protect against cadmium toxicity (Méplan et al, 1999). Since MCF7 cells were much more sensitive to cadmium toxicity as compared to HCC1806 and MDA-MB-231, a higher induction of MT in MCF7 cells may be required to protect against cytotoxicity and DNA damage.

The tumour suppressor protein p53 plays a role in regulation of cell cycle progression, DNA repair and apoptosis. The p53 activity is sensitive to oxidative stress and exposure to heavy metals. These conditions and DNA strand breaks can induce p53 and initiate apoptosis in cells. In order to understand the role of MT in apoptosis and the effect of p53, we have used epithelial cells with p53+/ $\mathrm{ER}+$ along with epithelial cells with p53-/ER -, and the results suggest that only MCF7 cells with p53+ can induce MT and induce apoptosis. The p53 activity may influence the expression of MT by several potential mechanisms. The p53 protein, which is a transcription factor, can activate or repress the expression of genes in 

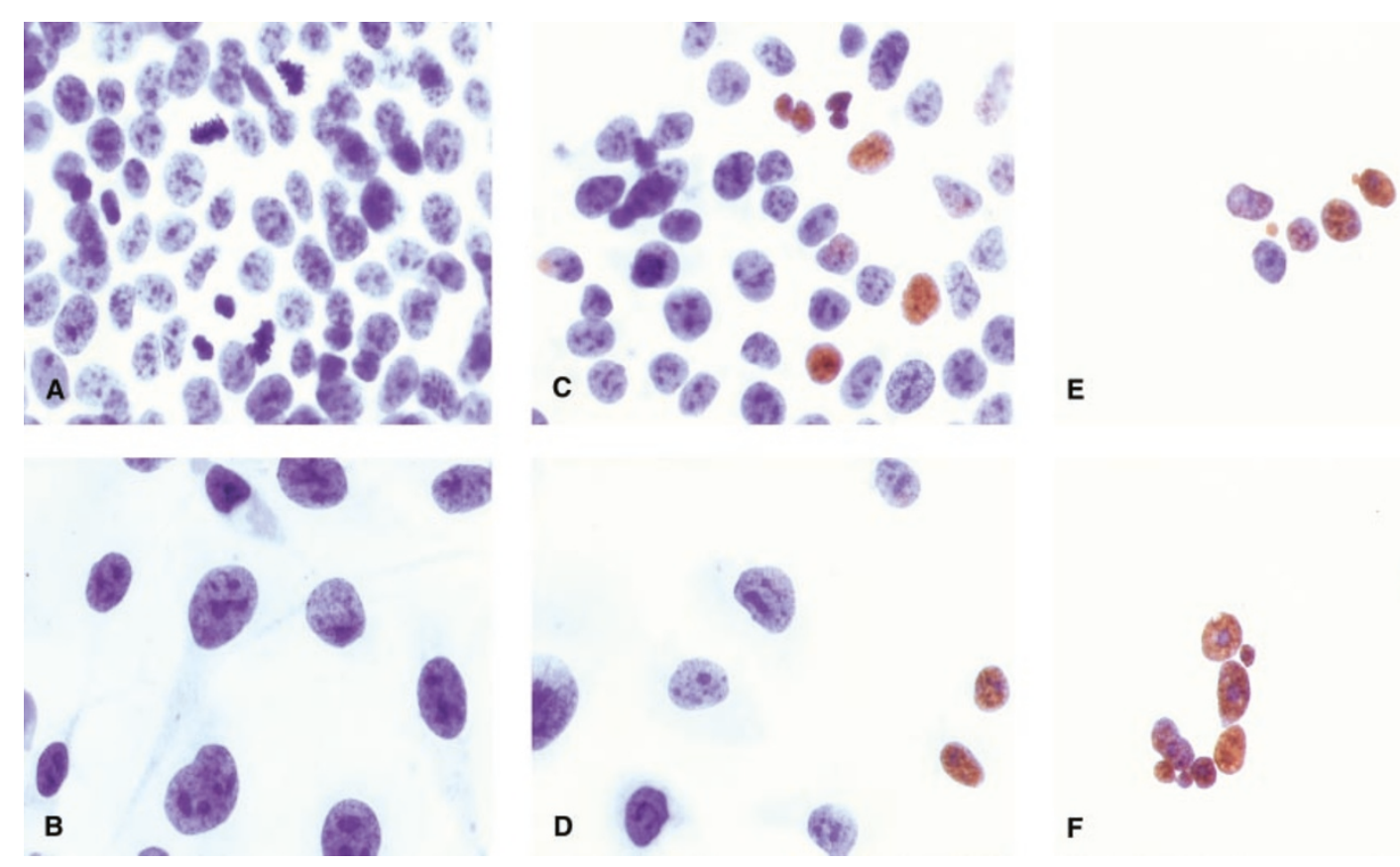

E

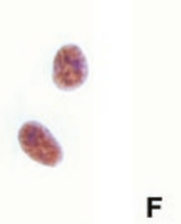

Figure 5 In situ detection of apoptotic bodies using TUNEL technique. Control cells: MCF7 (A), and MDA-MB-23I (B). Cells treated with $40 \mu \mathrm{M}$ CdCl 2 for 8 h: MCF7 (C), and MDA-MB-23I (D). Cells treated with $40 \mu \mathrm{M} \mathrm{CdCl} 2$ for 24 h: MCF7 (E), and MDA-MB-23I (F). TUNEL-positive apoptotic bodies are stained brown. Magnification $400 \times$.

A

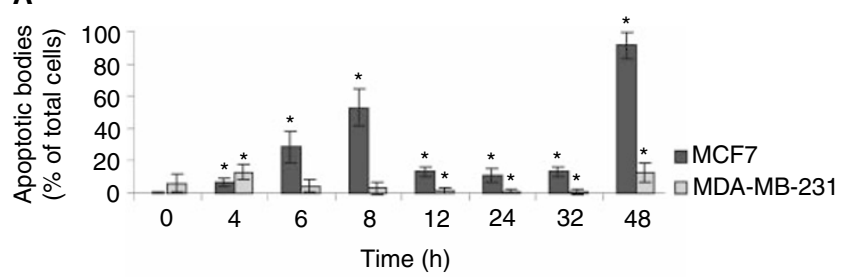

B

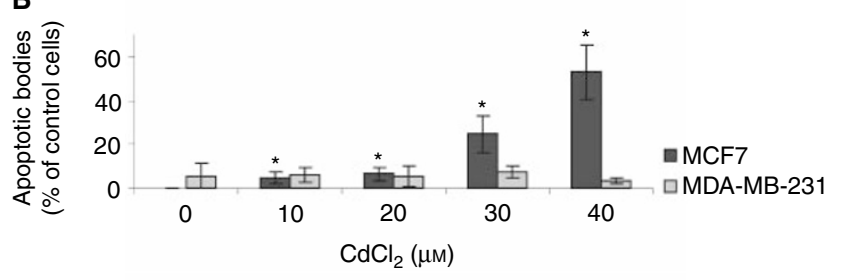

Figure 6 In situ detection of cadmium-induced apoptosis using the TUNEL technique. (A) MCF7 and MDA-MB-23I cells were treated with $40 \mu \mathrm{M} \mathrm{CdCl}$ for different time periods. (B) MCF7 and MDA-MB-23I cells were treated with various concentrations of $\mathrm{CdCl}_{2}$ for $8 \mathrm{~h}$. Apoptotic bodies were counted in randomly selected fields. Results are mean \pm s.e. of 10 randomly selected fields. *Significantly different from control at $P<0.05$.

anti-proliferative pathways (Agarwal et al, 1998). It has been demonstrated that zinc binding is crucial for p53 protein stabilisation and DNA binding (Hainaut and Milner, 1993). Since MT may be involved in zinc homeostasis, it can regulate the supply of zinc to p53 protein for its optimum activity and also protect the cells from toxicity to metals and free radicals. Lastly, zinc is known to inhibit the activation of both caspase 3 (Perry et al, 1997) and $\mathrm{Ca} / \mathrm{Mg}$-dependent endonuclease (Cohen and Duke, 1984), which play critical roles in the execution of apoptosis. MT, as a zinc bind-

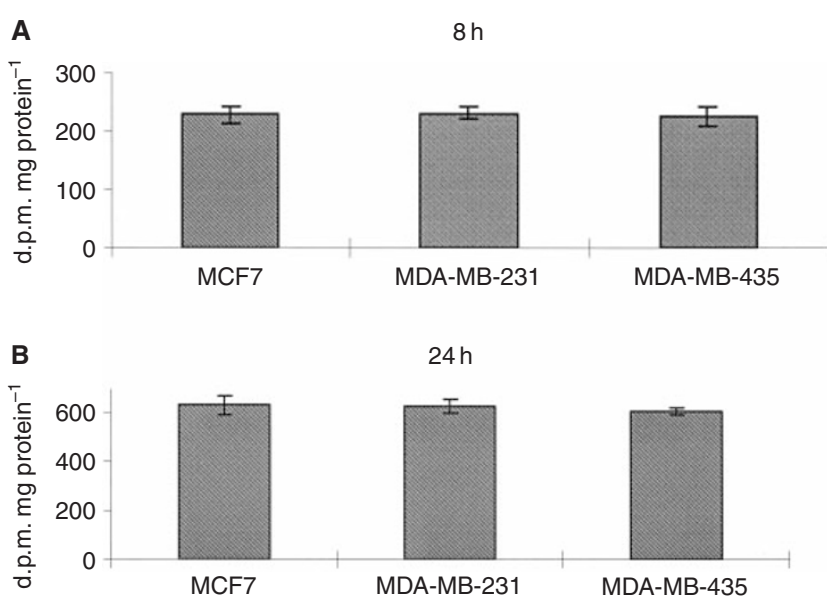

Figure 7 Uptake of $\mathrm{CdCl}_{2}$ by different cell lines. MCF7, MDA-MB-23। and MDA-MB-435 cells were treated with $10 \mu \mathrm{M}$ of ${ }^{109} \mathrm{CdCl}_{2}$ and disintegrations per minute (d.p.m.) were measured and expressed as d.p.m. mg protein $^{-1}$ at $(\mathbf{A}) 8 \mathrm{~h}$, and (B) $24 \mathrm{~h}$ after treatment. Results are mean \pm s.e. of three independent experiments.

ing protein, may also act as an anti-apoptotic factor. Thus, the expression of MT and p53 may play a critical role to determine whether cells undergo apoptosis or proceed to cell cycle stages.

The localisation of MT has important implications on its functions. Positive staining for MT has been demonstrated in various human tumours and can be localised in the cytoplasm and nucleus, often depending on cellular differentiation and proliferation (Cherian and Apostolova, 2000). Both MCF7 and HCC1806 cells showed mainly cytoplasmic staining for MT prior to induction with cadmium (Figure 3a,b). Nuclear staining noted in a few cells were associated with proliferative activity as noted by morphology in the immunohistochemical staining. However, following treatment with $10 \mu \mathrm{M} \mathrm{CdCl}_{2}$, intense staining for MT was observed in the nucleus 
and cytoplasm of MCF7 cells, but not in HCC1806 cells (Figure $3 c, d)$. The nuclear localisation of MT in MCF7 cells was associated with strong sensitivity towards cadmium-induced toxicity and the presence of $\mathrm{p} 53$. As mentioned, MT may participate in regulating p53 stability and DNA-binding activity, and in protecting cells against cadmium-induced toxicity, p53-induced reactive oxygen intermediates, and apoptotic DNA damage. These activities require MT to be present in the nucleus. This is in accordance with the suggested functions of nuclear MT: donation of zinc to transcription factors for DNA synthesis, regulation of gene expression, protection of the nucleus from oxidative damage, and protection of the DNA from damage and apoptosis (Cherian and Apostolova, 2000).

Activities of p53 are intricately linked to MT induction and localisation. p53 causes cell cycle arrest at G1 in response to low levels of stress (Schwartz and Rotter, 1998), and studies have shown localisation of MT in the nucleus occurs during G1/S phase when the requirement for zinc is highest (Cherian and Apostolova, 2000). p53 initiates apoptosis during high levels of stress (Schwartz and Rotter, 1998), and MT has been shown to play a role in different aspects of apoptosis. Further evidence is provided by a recent study showing that cadmium can affect the stability and DNAbinding activity of p53 (Méplan et al, 1999). In MCF7 cells, $10 \mu \mathrm{M}$ of $\mathrm{CdCl}_{2}$ caused an increase in $\mathrm{p} 53$ protein level and DNA binding activity. However, at higher concentrations $(20 \mu \mathrm{M}$ or greater), cadmium down-regulated p53 protein levels and DNA-binding. Interestingly, in the present study, MCF7 cells showed a strong induction of MT only when treated with $10 \mu \mathrm{M}$ $\mathrm{CdCl}_{2}$ and not higher concentrations $(20-50 \mu \mathrm{M}$, data not shown). This demonstrates a correlation between strong MT induction and p53 activity.

\section{REFERENCES}

Abdel-Mageed AB, Agrawal KC (1997) Antisense down-regulation of metallothionein induces growth arrest and apoptosis in human breast carcinoma cells. Cancer Gene Ther 4: 199-207

Agarwal ML, Taylor WR, Chernov MV, Chernova OB, Stark GR (1998) The p53 network. J Biol Chem 273: $1-4$

Aschner M, Conklin DR, Yao CP, Allen JW, Tan KH (1998) Induction of astrocyte metallothioneins (MTs) by zinc confers resistance against the acute cytotoxic effects of methylmercury on cell swelling, $\mathrm{Na}+$ uptake, and $\mathrm{K}+$ release. Brain Res 813: $254-261$

Cai L, Koropatnick J, Cherian MG (1995) Metallothioneins protect DNA from copper-induced but not iron-induced cleavage in vitro. Chem Biol Interact 96: 143 - 155

Cai L, Koropatnick J, Cherian MG (1996) Metallothionein and DNA damage. In Biological Effects of Low Level Ionizing Radiation and Molecular Biology Research, Gong SL (ed) pp 77-88. Chanchun: Norman Bethune University of Medical Sciences

Cai L, Wang GJ, Xu ZL, Deng DX, Chakrabarti S, Cherian MG (1998) Metallothionein and apoptosis in primary human hepatocellular carcinoma (HCC) from Northern China. Anticancer Res 18: 4667-4672

Cai L, Satoh M, Tohyama C, Cherian MG (1999) Metallothionein in radiation exposure: its induction and protective role. Toxicology 132: 85-98

Callahan R, Campbell G (1989) Mutations in human breast cancer: an overview. J Natl Cancer Inst 81: $1780-1786$

Cherian MG, Apostolova MD (2000) Nuclear localization of metallothionein during cell proliferation and differentiation. Cell Mol Biol 46: $347-356$

Chubatsu LB, Meneghini R (1993) Metallothionein protects DNA from oxidative damage. Biochem J 291: $193-198$

Cohen JJ, Duke RC (1984) Glucocorticoid activation of a calcium-dependent endonuclease in thymocyte nuclei leads to cell death. J Immunol 132: 38 42

Deng DX, Chakrabarti S, Waalkes MP, Cherian MG (1998) Metallothionein and apoptosis in primary human hepatocellular carcinoma and metastatic adenocarcinoma. Histopathology 32: $340-347$

Eaton DL, Cherian MG (1991) Determination of metallothionein in tissues by cadmium-hemoglobin affinity assay. Methods Enzymol 205: 83-88
Evidence points to a relationship between p53 and MT expression and induction in epithelial breast cancer cells. Higher basal MT expression is associated with p53 mutations in breast cancer cells (Friedline et al, 1998; Jin et al, 2000). Both factors indicate and may contribute to progression and poor prognosis of the cancer. In contrast, activation of p53 by cadmium is accompanied by high induction of MT. Besides protecting cells against cadmium-induced oxidative stress and DNA damage, MT may have an essential role in regulating p53 stabilisation and gene transcription, as well as protecting cells against p53-mediated apoptosis. Although the presence of ER may affect basal MT expression, the induction of MT seems to be unaffected by ER since cell lines weakly positive for ER did not show a significantly higher induction of MT compared to the cell lines negative for ER. Nonetheless, further studies are needed to ascertain the roles of p53 and ER in MT expression and induction. Additionally, more extensive work with different cell types may help to determine the tissue-specificity of any effect of p53 on MT induction.

\section{ACKNOWLEDGEMENTS}

We thank Dr Rodenheiser for providing the epithelial breast cancer cell lines MCF7 and HCC1806; Drs Laird and Lala for the cell lines MDA-MB-231, MDA-MB-468 and HS578t; and Drs Ferguson and Koropatnick for the cell line MDA-MB-435. All these investigators are from the University of Western Ontario, London, Ontario, Canada. This research was supported by the grants CIHR and NSERC.

El Azzouzi B, Tsangaris G, Pellegrin O, Manuel Y, Benveniste J, Thomas Y (1994) Cadmium induces apoptosis in a human T cell line. Toxicology 88: $127-139$

Friedline JA, Garrett SH, Somji S, Todd JH, Sens DA (1998) Differential expression of the MT-1E gene in estrogen-receptor-positive and -negative human breast cancer cell lines. Am J Pathol 152: 23-27

Goering PL, Klaassen CD (1984) Tolerance to cadmium-induced hepatotoxicity following cadmium pretreatment. Toxicol Appl Pharmacol 74: $308-$ 313

Greenstock CL, Jinot CP, Whitehouse RP, Sargent MD (1987) DNA radiation damage and its modification by metallothionein. Free Radic Res Commun 2: $233-239$

Haerslev T, Jacobsen K, Zedeler K (1995) The prognostic significance of immunohistochemically detectable metallothionein in primary breast carcinomas. APMIS 103: 279-285

Hainaut P, Milner J (1993) A structural role for metal ions in the wild-type conformation of the tumour suppressor protein p53. Cancer Res 53: $1739-1742$

Hart BA, Lee CH, Shukla GS, Shukla A, Osier M, Eneman JD, Chiu JF (1999) Characterization of cadmium-induced apoptosis in rat lung epithelial cells: evidence for the participation of oxidant stress. Toxicology 133: 43-58

Jin R, Bay BH, Chow VT, Tan PH, Lin VC (2000) Mettalothionein 1E mRNA is highly expressed in oestrogen receptor-negative human invasive ductal breast cancer. Br J Cancer 83: 319-323

Joseph MG, Banerjee D, Kocha W, Feld R, Stitt LW, Cherian MG (2001) Metallothionein expression in patients with small cell carcinoma of the lung. Correlation with other molecular markers and clinical outcome. Cancer 92: $836-842$

Karin M, Haslinger A, Holtgreve H, Richards RI, Krauter P, Westphal HM, Beato M (1984) Characterization of DNA sequences through which cadmium and glucocorticoid hormones induce human metallothioneinIIA gene. Nature 308: 513-519

Klaassen CD, Liu J, Choudhuri S (1999) Metallothionein: an intracellular protein to protect against cadmium toxicity. Annu Rev Pharmacol Toxicol 39: $267-294$ 
Kondo Y, Woo ES, Michalska AE, Choo KH, Lazo JS (1995) Metallothionein null cells have increased sensitivity to anticancer drugs. Cancer Res 55: $2021-2023$

Lazo JS, Kuo SM, Woo ES, Pitt BR (1998) The protein thiol metallothionein as an antioxidant and protectant against antineoplastic drugs. Chem Biol Interact 111-112: 255-262

Méplan C, Mann K, Hainaut P (1999) Cadmium induces conformational modifications of wild-type p53 and suppresses p53 response to DNA damage in cultured cells. J Biol Chem 274: $31663-31670$

O’Connor PM, Jackman J, Bae I, Myers TG, Fan S, Mutoh M, Scudiero DA, Monks A, Sausville EA, Weinstein JN, Friend S, Fornace AJ, Kohn KW (1997) Characterization of the p53 tumor suppressor pathway in cell lines of the national cancer institute anticancer drug screen and correlations with the growth-inhibitory potency of 123 anticancer agents. Cancer Res 57: $4285-4300$

Oyama T, Takei H, Hikino T, Lino Y, Nakajima T (1996) Immunohistochemical expression of metallothionein in invasive breast cancer in relation to proliferative activity, histology and prognosis. Oncology 53: $112-117$

Perry DK, Smyth MJ, Stennicke HJ, Salvesen GS, Duriez P, Poirier GG, Hannun YA (1997) Zinc is a potent inhibitor of the apoptotic protease, caspase-3. J Biol Chem 272: $18530-18533$

Runnebaum IB, Hagarajan M, Bowman M, Soto D, Sukumar S (1991) Mutations in p53 as potential molecular markers for human breast cancer. Proc Natl Acad Sci USA 88(23): $10657-10661$

Sato M, Bremner I (1993) Oxygen free radicals and metallothionein. Free Radical Biol Med 14: 325-337

Schwartz D, Rotter V (1998) P53-dependent cell cycle control: response to genotoxic stress. Semin Cancer Biol 8: 325-336
Schwarz MA, Lazo JS, Yalowich JC, Reynolds I, Kagan VE, Tyurin V, Kim YM, Watkines SC, Pitt BR (1994) Cytoplasmic metallothionein overexpression protects NIH 3T3 cells from tert-butyl hydroperoxide toxicity. J Biol Chem 269: $15238-15243$

Scudiero DA, Shoemaker RH, Paull KD, Monks A, Tierney S, Nofziger TH, Currens MJ, Seniff D, Boyd MR (1988) Evaluation of a soluble tetrazolium/formazan assay for cell growth and drug sensitivity in culture using human and other tumour cell lines. Cancer Res 48: 4827-4833

Symonds H, Krall L, Remington L, Saenzrobles M, Lowe S, Jacks T, Vandyke $\mathrm{T}$ (1994) P53-dependent apoptosis suppresses tumor-growth and progression in-vivo. Cell 78: $703-711$

Tsangaris G, Tzortzatou-Stathopoulou F (1998) Cadmium induces apoptosis differentially on immune system cell lines. Toxicology 128: $143-150$

Woo ES, Lazo JS (1997) Nucleocytoplasmic functionality of metallothionein. Cancer Res 57: 4236-4241

Yang CF, Shen HM, Shen Y, Zhuang ZX, Ong CN (1997) Cadmium-induced oxidative cellular damage in human fetal lung fibroblasts (MRC-5 cells). Environ Health Perspect 105: $712-716$

Zeillinger R, Tantscher E, Schneeberger C, Tschugguel W, Eder S, Sliutz G, Huber JC (1996) Simultaneous expression of nitric oxide synthase and estrogen receptor in human breast cancer cell lines. Breast Cancer Res Treat 40(2): $205-207$

Zhou T, Zhou G, Song W, Eguchi N, Lu W, Lundin E, Jin T, Nordberg G (1999) Cadmium-induced apoptosis and changes in expression of $p 53, c$ jun and MT-I genes in testes and ventral prostate of rats. Toxicology 142: $1-13$ 